\title{
A Study of Implicature in Daredevil Web Series Movie
}

\author{
${ }^{1}$ Isnaini Jalu Rakhmat Prakoso, ${ }^{2}$ Fauzia \\ Universitas Ahmad Dahlan \\ 1jalurp22@gmail.com, ${ }^{2}$ fauzia@pbi.uad.ac.id
}

\begin{abstract}
People especially them who use English as foreign language tend to feel difficult to understand the implicature, they need to infer the implicature in order to get what the actors mean in a movie. This study is aimed to identify the implicature and their maxim violation and find out how the violating maxims occur in Daredevil web series movie.

The study is conducted by using a mixed (qualitative-quantitative) method. The research object of this study is about implicature and the violation of the maxim. The subject of this study is a web series movie script entitled Daredevil, the scripts are taken from season 1 episode 1 until 3. To collect the data, the writer uses note taking technique. The writer uses pragmatic referential method (metode padan pragmatis) to analyze the data qualitatively, and then count the frequencies of the data quantitatively.

The result shows 25 implicatures in Daredevil web series movie that occur because of its violation of the maxim. There are $20 \%$ implicature by violating the maxim of quantity, $36 \%$ implicature by violating the maxim of quality, $26 \%$ implicature by violating the maxim of relation, $18 \%$ implicature by violating the maxim of manner. By violating the maxim, the characters produce some implied meanings which can be used to misleading the hearer. The implied meaning of the utterances refers to an expression of agreement, denial, refusal, acceptance and indirect sentence, it depends on how the character uses the implicature.
\end{abstract}

Keywords: Pragmatics, Context, Cooperative Principle, Implicature, Violating Maxim

How to Cite: Prakoso, I.J.R. and Fauzia, F. (2018). A study of implicature in daredevil web series movie. English Language Teaching Educational Journal, 1(1), 106-114.

\section{INTRODUCTION}

People communicate with language. Crystal (2008) has written in his book that "language is an act of speaking, writing or signing in a given situation - the notion of parole, or performance". Thus, language is a system which is used by human to communicate, share feelings and ideas through verbal and nonverbal activities. When people talk using language, there are times when humans say (or write) precisely what they mean. However, in some cases, people tend to say (or write) far from the words meaning or something entirely different from the phrase means. Something above is covered in linguistics. Linguistics "may be defined as the scientific study of (Lyons, 1968). Linguistics concerns about the nature of language and communication. In linguistics contexts are studied in pragmatics. Pragmatics is the study of speaker meaning, contextual meaning and it is a study of how more communicated than it said also a study about the expressions of relative distance (Yule \& Stalnaker, 1996). 
The language which is studied by pragmatics not only about a written language however, a conversation is concerned too. Where conversation happens it means that there is communication. Communication involves two participants who are speaker and hearer. Leech (1983) explains that speaker is someone who receives and interprets the message while hearer is the one who gets or becomes the target of the message. Language is used in communication and produces utterances in a particular context. To make an efficient and accurate communication the speaker and the hearer should co-operate each other for misunderstanding may occur in a conversation.

People tend to misunderstood in understanding the implicature because of lack of knowledge about it. Moreover implicature has many types and rules. Grice (1975) in Thomas (1995) said that there are two types of implicature: conventional and conversational implicature. Conventional implicature occurs when there is no need of special knowledge and special background of knowledge to make the necessary inferences. Conversational implicature; positive response is agreement and acceptance, negative response means denial, refusal, mockery, complaint, and lie. There are four maxims in conversational implicature which are quantity, quality, relation, and manner. When a speaker observes all the maxims and precisely said what they mean, they generated no implicature. However, many occasion when people fail to observe the maxims. There are five types distinguished by Grice (1975) in Thomas (1995) that the speaker is not able to observe a maxim; they are floating, violating, Infringing, opting out, and suspending.

The problem arises when people realize that actually implicature has many type and rules as mentioned above. People need to observe the context and pay attention to the maxims which is broken in order to get the actual meaning without any miscommunication.

The writer will focus on the violating a maxims in the Daredevil web series movie implicature. The main reason is because people tend to use the term 'violate' to generate the implicature. However the violating maxims itself has its own rules to occur. That is the reason why the researcher only focused on violating of the maxim implicature.

The subject of this study is an American web television series created for Netflix by Drew Goddard called Marvel's Daredevil, or simply Daredevil, is a movie based on Marvel's Daredevil comic by Stan Lee and Bill Everett, while the object of the research in this study is violating a maxim in an implicature.

\section{Implicature}

(Thomas, 1995) argues that an implicature refers to anything that infers from an utterance but that is not a condition for the truth of the utterance. There is a hidden message from speakers that they want to tell.

People use implicature for some reasons. For example, implicature applied to sarcastic, implying humor, or delivering the different intention from the speech act usage. Grice (1975) as cited in Thomas (1995) distinguished two different short of implicature: conventional implicature and conversational implicature. Conventional implicature occurs when there is no need of special 
knowledge and special background of knowledge to make the necessary inferences. In the case of conventional implicature the same implicature is always conveyed, regardless of the context whereas in the case of conversational implicature, what is implied varies according to the context of utterance (Thomas, 1995). There are two basic conjunctions of conventional implicature: but, therefore (Levinson, 1983).

However the conversational implicature is not as simple as it is, the example above is just an example of an introduction of how an implicature works. Because there is so many factors which make the implicature occur. Conversational implicature needs context in order to understand what is the meaning carried by the implicature. The positive response is agreement and acceptance and the negative response means denial, refusal, mockery, complaint, and lie. This kind of phenomenon is discussed by Thomas (1995) that implicature occurs when the speaker is breaking the rules of a good conversation. The rule is called as cooperative principles, in order to get a meaningful conversation speaker should fulfill the maxim, and there are four maxims in conversational implicature which are quantity, quality, relation, and manner. If the speaker fulfills the maxim, there will be no implicature. On the other hand, if the speaker is not able to fulfill the maxim, conversational implicature arises only in a particular context of utterance.

\section{Cooperative Principle}

The cooperative principle is a rule of conversation when the participants expect that each will make a "conversational contribution such as is required, at the stage at which it occurs, by the accepted purpose or direction of the talk exchange" (Thomas, 1995). The cooperative principle is a cooperative activity which is done by the speaker and the hearer. As a cooperative activity which is done by the both speaker and hearer.

The principles are called maxims. The maxims are divided into a maxim of quality, a maxim of quantity, a maxim of relevance or relation, and the maxim of manner. However, there is a situation that the speaker or the hearer does not behave cooperatively. Which mean the cooperative principle is observed or nonobserved. When the speakers can fulfill the maxims of Cooperative Principle, it indicates that the observed cooperative principle is done and the speaker will be considered as cooperative in a conversation. However, when the speakers are not able to fulfill the maxims, there will be a non-observed cooperative principle and the implicature will arise.

\section{a. Observed Cooperative Principle}

Observed cooperative principle occur when the speakers can fulfill the maxims of Cooperative Principle, it indicates that the speaker will be considered as cooperative in a conversation. Grice (1975) as cited in Thomas (1995) has formulated the maxims as follow: 
1) Maxim of Quantity: The speaker must make a contribution as informative as is required (for the current purpose of the exchange). The speaker is not permitted to make more informative information than is required.

2) Maxim of Quality: The speaker is not allowed to not say what you believe to be false. It requires the speaker to be honest to the hearer.

3) Maxim of Relation: The speaker should be relevant. The speakers should say something which is relevant to the previous saying in a conversation.

4) Maxim of Manner: The speaker must avoid obscurity of expression, ambiguity. The speaker must be brief (avoid unnecessary prolixity) and orderly.

\section{b. Non-observed Cooperative Principle}

Based on Thomas (1995) book, non-observed Cooperative Principle is a condition when speakers cannot fulfill the maxims of Cooperative Principle. When saying something people fail to observe the maxims. There are five of implicature that occur because the speaker is not able to observe a maxim; they are floating, infringing, opting out, suspending, and violating.

1) Floating the maxims

Floating maxim quantity is known when the speaker is giving less or more information than is needed. Floating maxim quality is interpreted as giving some information that does not represent what they think. In floating maxim relation, the hearer is expected to imagine the utterance which is not said as the answer to the question. The last type is floating maxim manner. It is done by being obscure and often excludes a third party.

2) Infringing the maxim

Another type of non-observed maxim is infringing the maxim. It can be considered as a failure of observing the conversational maxims, for the imperfection of the linguistics performance for several reasons. Infinging of the maxim can be seen in the baby's talk or foreign language learner who is not able to speak clearly, nervous, drunk, scared and cognitive impairment people.

3) Opting out the maxim

Opting out the maxim means that the speaker is unwilling to cooperate because of certain reasons.

4) Suspending the maxim

This maxim is failed to be observed and occurs when there are few words or sentences are inappropriate or taboo to say. Usually, this condition happens in the case of the mention of the name, place or thing. Then culture, place, time, and the situation will also affect the violation of this maxim. The audience also did not expect the speaker clarifies what the speaker meant because the listener already knew the meaning. To make the interlocutor understand, the speaker will be looking for the pronouns such taboo words.

5) Violating maxims 
The last type of the Non-observance of the Conversational Maxims is violating maxims. Speaker violated the maxims when the speaker gives the wrong information intentionally, that the hearer will know the literal meaning of the utterance only. There are four types of violating maxims. They are violating quality, violating quantity, violating relation, and violating manner.

\section{RESEARCH METHOD}

In this study the writer uses a mixed (qualitative-quantitaive) method. The writer uses pragmatic referential method (metode padan pragmatik) to analyze the data qualitatively. Referential method is a method which is used to identify the rule in the analyzing step (Sudaryanto, 2015). And then to count the frequencies of the data, the writer uses quantitatively method. Vanderstoep and Johnson (2009) state in general that, quantitative research specifies numerical assignment to the phenomena under study.

The data of this study is dialogue in the script of the Daredevil web-series movie containing implicature especially about violating maxims. The subject of this study is an American web television series created for Netflix by Drew Goddard called Daredevil. The object of the research in this study is violating a maxim in an implicature.

\section{FINDINGS AND DISCUSSION}

1. Description of the Non-Observed Cooperative Principle Occurs in the Conversation in Daredevil Web Series Movie

After identifying the data, the writer finds twenty-five (25) implicature utterances uttered by the characters. The writer classify those 25 implicature utterances, the data based on the non-observed cooperative principle that is produced by violating the four maxims. The findings which the writer finds based on the frequency of the occurrences of the maxis that produce implicature are presented in the table below:

Table 1. Frequency of the Implicature Occurrence

\begin{tabular}{cccc}
\hline No & The Non Observed Cooperative & $\begin{array}{c}\text { Number of } \\
\text { Principle }\end{array}$ & $\%$ \\
\hline 1 & violating of the maxim quantity & 5 & $20 \%$ \\
2 & violating of the maxim quality & 9 & $36 \%$ \\
3 & violating of the maxim relation & 7 & $26 \%$ \\
4 & violating of the maxim manner & 4 & $18 \%$ \\
\hline
\end{tabular}

Speaker violated the maxims when the speaker gives the wrong information intentionally, that the hearer will know the literal meaning of the utterance only. The implicature which happens because of the violation of the maxim is divided into four types which are explained above. Those are the 
violating of the maxim quantity, violating of the maxim quality, violating of the maxim relation, violating of the maxim manner.

\section{a. The Implicature Generated by Violating the Maxim of Quantity}

The speaker must make a contribution as informative as is required (for the current purpose of the exchange). The speaker is not permitted to make more informative information than is necessary. The implicature in Daredevil web series movie has violated the principle, here is an example

(1) Matt : Here's how this is gonna work. I'm gonna ask you some questions. You're gonna answer them. If you're lying to me, trust that I will know, and I will be unhappy. Where's the boy?

Foster : He's dead.

After in the last scene Foster feels that Claire hides something to him, he decided to call his Russian's gang to catch Matt. However Matt realizes, he attack Foster and brings him to the roof and interrogates him. After Matt asks questions, here Foster violates the maxim of quantity by saying He's dead. Since he only gives less information that is needed by Matt the Daredevil about the boy that they kidnaped on the last episode.

\section{b. The Implicature Generated by Violating the Maxim of Quality}

The speaker is not allowed to not say what you believe to be false. It requires the speaker to be honest to the hearer. Some implicatures in Daredevil web series movie are violating the maxim. It can be analyzed through the example below:

(2) Claire : (Whispers) Please. (Knocking continues). Who is it?

Foster : NYPD, ma'am. Please open the door.

Foster answer indicates that he has violated the maxim of quality. In order to capture Matt Murdock he has lied to Claire by saying "NYPD, ma'am", however he is not a real NYPD (New York Police Department) officer. He does that because he does not Claire know that he is one of the members of the Russian gangster which wants to capture Matt.

\section{c. The Implicature Generated by Violating the Maxim of Relation}

In the rule of Maxim of Relation, the speaker should be relevant. The speakers should say something which is relevant to the previous saying in a conversation. Some dialogue in this movie has generates implicature that occur because the actors has violated the maxim of relation, here are some examples:

(3) Matt : You find anything?

Claire: (Holding Foster's phone). You smashed the hell out of it with that extinguisher. He had a badge. What if you're wrong?

In this conversation, Claire is violating the maxim of relation. She gives irrelevant answer by saying "(Holding Foster's phone). You smashed the hell out of it with that extinguisher. He had a badge. What if you're wrong?", 
her response is not relevant with Matt's question. She disobey the rule of "be relevant" by saying that statement.

\section{d. The Implicature Generated by Violating the Maxim of Manner}

The speaker must avoid obscurity of expression, ambiguity. The speaker must be brief (avoid unnecessary prolixity) and orderly. Some dialogues have brought up the implicature by violating the maxim of manner can be seen from the dialogues as follow:

(4) Matt : This is what unhappy looks like. Where's the boy?

Foster : What do you care? If he's not dead yet, he will be.

The conversation happens between Matt Murdock or Daredevil and Foster the member of Russian gang who is interrogated by Matt. Foster is violated the maxim of manner, because the rule of this maxim is "avoid the obscurity expression'. And Foster answer generates the implicature by violating the maxim of manner because by saying "What do you care? If he's not dead yet, he will be." He seems obscure. He should give answer not question.

\section{Description of Implied Meaning of Utterances Uttered by the Characters Containing Implicature in Daredevil Web Series Movie}

The implied meaning generates the reason why the characters use the implicature. The conversation which violate the maxim and generate implicature will have implied meaning. The implied meaning can be seen in the form of yes no question which uttered by the character in the Daredevil web series movie dialogues.

Some kind of expression can be seen in the Daredevil web series movie implicature implied meaning. They tend to use indirect answer to say yes or no rather than say it explicitly. Some kind of examples which show the agreement expression can be seen from the dialogues as follows:

(5) Urich : So that's it? That's all I get?

Man : You know, when I went away to do my 10, every newspaper in town dragged my name through the shit. You were the only one who did it without mentioning my kids. Always grateful for that.

This conversation happens between Ben Urich and his friend, Urich want to get information but cost of something which can threaten their life but, the man does not want to give the information because he thinks that it is the way too dangerous for him. By saying "You know, when I went away to do my 10, every newspaper in town dragged my name through the shit. You were the only one who did it without mentioning my kids. Always grateful for that." The man already violates the maxim of relation. Moreover by saying his answer, he also 
gives example of the agreement expression that means he refuse to give the information, because back in time he got problem and Urich is the only one who helped him. He does not give yes answer because his utterance has already implied that he will stop giving information.

\section{CONCLUSION}

After analyzing the data in Daredevil web-series movie, the writer has found that there is implicature occurs by violating the maxim in this movie. There are 25 implicature utterances uttered by the characters in this movie episode 1 until 3 in the first season. From the 25 utterances is classified into the maxim which is violated by the characters. Those maxims are violating of the maxim quantity, violating of the maxim quality, violating of the maxim relation, violating of the maxim manner. The final result of the data analysis found that there are five (5) implicature utterances generated by violating maxim of quantity, nine (9) implicature utterances produced by violating maxim of quality, seven (7) implicature utterances produced by violating maxim of relation, four (4) implicature utterances generated by violating maxim of manner. The most often appear implicature is implicature which occurs by violating the maxim of quality which is $36 \%$ while the least is the violation of the maxim of manner which is $18 \%$ by the frequency of appearance.

The writer also finds more findings that the implicature in Daredevil Web Series Movie by violating the maxim utterances uttered by the characters has implicit meaning. To understand how the implicature occurs the writer identifies the context of the utterances. The characters on the Daredevil web-series movie tend to use the indirect response to deliver their answer because of a certain reason. In this study, the implied meaning in the implicature that occurs because of the violating of the maxim is usually a refusal or agreement in the form of yes or no question.

\section{REFERENCES}

Crystal, D. (2008). Dictionary of linguistics and phonetics. New Jersey: Blackwell Publishing.

Daredevil Web Series Movie Script. (2015). Retrieved April 27, 2017, from https://genius.com > D > Daredevil

Daredevil. (2015) Retrieved March 2, 2017, from www.netflix.com/title/80018294

Daredevil Web Series Movie Script. (2015). Retrieved April 20, 2017, from www.springfieldspringfield.co.uk/episode_scripts.php?tvshow=daredevil -2015

Daredevil Web Series Movie Script. (2015). Retrieved May 1, 2017, from www.simplyscripts.com/scripts/DAREDEVIL-PILOT.pdf 
Leech, G. N. (1983). Principles of pragmatics. New York: Longman Group Limited.

Levinson, Stephen C. (1983). Pragmatics. New York: Cambridge University Press.

Lyons, J. (1968). Introduction to theoretical linguistics. New York: Cambridge University Press.

Sudaryanto. (2015). Metode dan aneka teknik analisis bahasa.Yogyakarta: Sanata Dharma University Press.

Thomas, Jenny A. (1995). Meaning in interaction: An Introduction to Pragmatics. New York: Routledge.

VanderStoep, S., \& Johnston, D. (2009). Methods for blending qualitative and quantitative approaches. San Francisco: Jossey-Bass.

Yule, G., \& Stalnaker, R. (1996). Pragmatics. Oxford: Oxford University Press. 